\title{
Saving Lives: Timely Flash Flood Warnings in the UK
}

\author{
Colin Clark \\ CHRS Shute Lane, Bruton, Somerset, UK \\ Email: colin4chrs@hotmail.com
}

How to cite this paper: Clark, C. (2017) Saving Lives: Timely Flash Flood Warnings in the UK. Journal of Geoscience and Environment Protection, 5, 60-74. https://doi.org/10.4236/gep.2017.52005

Received: November 10, 2016 Accepted: February 7, 2017

Published: February 14, 2017

\begin{abstract}
Flash floods are a major cause of death and destruction to property on a worldwide scale. In the UK sudden flooding has been the cause of the loss of over 60 lives during the last century. Forecasting these events to give enough warning is a major concern: after the 2004 flood at Boscastle, Cornwall UK the Environment Agency (2004) stated that it was not possible to provide a warning in such a fast reacting and small catchment. This is untrue since the Agency had already implemented a real time non-linear flow model as part of a flood warning system on the upper Brue in Somerset UK. This model is described in this paper as it has been applied to the Lynmouth flood of 1952, and briefly for the Boscastle catchment, both of which have an area of about 20 $\mathrm{km}^{2}$. The model uses locally measured SMD and saturated hydraulic conductivity data. With the addition of further parameters the model has been successfully used nationwide.
\end{abstract}

\section{Keywords}

Flash Floods Flood Warning Non-Linear Flow Model Historic Floods

\section{Introduction}

Flash flooding in the UK has been a major cause of water related deaths during the 20th century. The worst of these events was the Lynmouth flood disaster in which 34 people were drowned in 1952. This is followed by the Louth flood of 1920 in which 23 souls were lost. More recently people have been drowned during the floods of 1958 (Boscastle), 1968 (Mendip), 1998 (Midlands), 2007, 2009 and 2012. For those who survive such ordeals the psychological effects can be dramatic [1]. Having suffered such losses in the past the authorities have been woefully slow to provide good quality flood warnings. Sene [2] provides an overview of the methods used to warn people of serious flooding. The requirements for warnings include rainfall and radar data [3], soil moisture deficit data 
[4] [5], and for some probabilistic forecast methods [6] [7] [8] suggest that improvements in data collection, assimilation and modelling are needed, as are the human responses to flood warnings. Real time flood warning systems are not yet the norm in the UK. There is too much reliance on radar data which is either not detailed enough for small catchments or is simply inaccurate [3]. Following recent flooding the UK Government produced a review of flood resilience [9]. This tended to focus on the provision of rainfall simulations for probabilistic forecasting, the effects of climate change, but missed out small scale effects such as neglected drainage ditches and road levels becoming higher than household thresholds over a long period of successive road resurfacing. While there has been a call to replace the 1 in 100 year style of describing a flood [10] since it is said to be "confusing" to the public, the general level of understanding of flood frequency and especially flash flooding is so low that a much more practical approach is needed. This is especially true for surface water flooding which in the main, is caused by changes in surface hydraulic properties and inadequate road drainage, especially raised road levels. For example, in the Upper Brue at Bruton the main road has been raised by $0.5 \mathrm{~m}$ in the past 150 years, and at Combe in Oxfordshire the road had been raised about $0.3 \mathrm{~m}$ which led to floodwaters entering nearby houses. While flash floods caused by surface water is unlikely to cause death from drowning a much more serious risk is from river flooding in small rural catchments. The Land Drainage Act [11] states that where a flood warning system can be produced and is requested, the authorities have a duty to act accordingly. However, the level of understanding following the Boscastle flood of 2004 in Cornwall UK can be summed up:

"It's not possible to accurately forecast flooding in some areas such as parts of north Cornwall, where steep valleys mean that rivers can rise so rapidly after heavy rain that, with current technology, there's not enough time to issue warnings" [12].

However, a real time warning system had already been provided for the upper Brue [13] and which was tested against the smaller Valency river at Boscastle where the catchment area is $20 \mathrm{~km}^{2}$, to give 1 hour warning on 16th August 2004 [14]. The non-linear flow model has now been extended over the whole of England and Wales [15] for design flood estimation, and with suitable soil hydraulic conductivity data it can be tested against actual storm events such as the most severe flood that has ever taken place in recent history, namely the Lynmouth flood on the East and West Lyn. whose catchment areas are $77 \mathrm{~km}^{2}$ and $22 \mathrm{~km}^{2}$ respectively. To date, this is the most severe test of the method. While Ciervo et al. [16] have used post event surveys to simulate a flash flood the present example is the first which uses both real time rainfall measurements and soil data gathered in the field. In addition where there is a significant soil moisture deficit at the start of the storm the model uses field based measurements of SMD which have been found to be much more reliable than calculated values [5]. It is contended that only with locally based field measurements can reliable flood warnings for fast reacting catchments be made both in the UK and elsewhere. This approach is in contrast to WMO [17] which states: "The difficulty of in situ 
monitoring of catchment wetness by conductivity or lysimeter measurements makes the use of these techniques very uncommon in flood forecasting operations".

The remainder of this paper will give a description of the evolution of the flow model, how it has been tested in over 600 catchments in England and Wales, and how the measurement of in situ SMD has been carried out using low cost weighing lysimeters. Unlike some flow models which are computationally demanding, the current model can be used on an ordinary PC. With the SMD data posted daily on a website it can be accessed and input to the model. The model can also be used to produce flood frequency estimates. These are made more robust when field surveys of bankfull discharge are made, which in many rivers worldwide has a frequency of about $1.1-2.0$ years. While the biggest catchment that the model has been tested is around $650 \mathrm{~km}^{2}$ it is on small flashy catchments that its value for providing timely warnings may be appreciated.

\section{The Nonlinear UH Flow Model}

The Unit hydrograph (UH) method has a long history being based on the work of Sherman [18]. Young and Bevan [19] have used a non-linear response since it is widely recognised that many hydrological processes are non-linear. The need to model non-linear responses in hydrology has also been promoted by Sivakumar [20]. The unit hydrograph method needs the following data and analysis in order to produce an estimate of the flood before the flood arrives:

1) Real time measurement of storm rainfall intensities

2) The antecedent soil moisture deficit (SMD) based on weighing lysimeter observations

3) An estimate of slope runoff when the SMD is zero

4) The percentage runoff at each stage of the storm event based on measured soil hydraulic conductivity

5) Conversion of the runoff depth into quickflow discharge

6) Conversion of the remaining rainfall into delayed flow discharge

7) Summation of quickflow and delayed flow to give total discharge

The first version of the flow model was developed as a flood warning tool for the Environment Agency to be used for flood warning at Bruton in East Somerset which is situated below a flood detention dam [13]. The approach to calibration of the model is data based mechanistic in that the autographic rainfall and estimates of peak discharge and timing of the flood events of 1968, 1974, 1979, and 1982 were used to produce the algorithms. The non-linear behaviour of the upper Brue catchment with an area of $31 \mathrm{~km}^{2}$ suggested that the change in discharge rate was of a logistic borrowed from biology which mimics autocatalytic monomolecular reactions Street \& Opik, [21]:

$$
\log \mathrm{x} / \mathrm{a}-\mathrm{x}=\mathrm{k}\left(\mathrm{t}-\mathrm{t}_{1}\right)
$$

where $\mathrm{t}$ and $\mathrm{t}_{1}$ are time intervals, $\mathrm{k}=$ constant, $\mathrm{a}=$ maximum size, $\mathrm{x}=\mathrm{a}$ given value. 
This equation can be rewritten and optimised for the Brue dam site for the rising stage of the hydrograph:

$$
\mathrm{Y}=[\operatorname{INVLOG} 2(\mathrm{t}-0.7 \mathrm{Tp}) / 1+\operatorname{INVLOG} 2(\mathrm{t}-0.7 \mathrm{Tp})] \mathrm{Qp}
$$

where $\mathrm{Tp}=$ time to peak, $\mathrm{t}=$ time since start of storm, $\mathrm{Qp}=$ peak runoff rate per $\mathrm{mm}$ net rainfall and is related to Tp as follows:

$$
\mathrm{Qp}=(330 / \mathrm{Tp}) \mathrm{A} / 1000
$$

where $\mathrm{A}=$ catchment area $\left(\mathrm{km}^{2}\right)$.

For the falling limb:

$$
\mathrm{Y}=\left[\operatorname{INVLOG}\left(\mathrm{t}_{1}-0.85(\mathrm{~TB}-\mathrm{Tp})\right) / 1+\operatorname{INVLOG}\left(\mathrm{t}_{1}-0.85(\mathrm{~TB}-\mathrm{Tp})\right)\right] \mathrm{Qp}
$$

where $\mathrm{TB}=$ time base and is related to $\mathrm{Tp}$ as follows:

$$
\mathrm{TB}=2.52 \mathrm{Tp}
$$

The time interval $t_{1}$ is then related to TB as follows:

$$
\mathrm{t}_{1}=\mathrm{TB}-\mathrm{t}
$$

The delayed flow was calculated using a maximum value of $0.3896 \mathrm{~m}^{3} \cdot \mathrm{s}^{-1} \cdot \mathrm{mm}^{-1}$. There is a time lag of 2 hours before delayed flow starts and a further 2 hour delay for peak delayed flow to occur. Thereafter a linear decay function was used. The model was calibrated using the storm events of 1968, 1974, 1979, and 1982. For these events the time to peak decreased with increasing rainfall intensity (13), and by implication storm rarity, an observation that has been noted elsewhere [22]. The relationship between maximum rainfall intensity $(\mathrm{R})$ and time to peak $(\mathrm{Tp})$ :

$$
\mathrm{Tp}=(2.4073 \mathrm{R}+10.1005) / \mathrm{R}
$$

There are no measured flow records for the upper Brue but autographic measurements of rainfall have been made at North Brewham since 1966. As a further check, the estimated rainfall hyetograph of the 1917 storm [23] was also used. The results are shown in Table 1.

These were based on field observations of the timing of over-bank and peak discharge and estimates of the peak discharge based on hydraulic calculations [24].

The result for the 1917 storm gave a peak discharge similar to that estimated from wrack marks and hydraulic calculations.

The flow model was adopted by the Environment Agency during 2004 and has

Table 1. Comparison of estimated peak discharge (cumecs) in the field and using the runoff model.

\begin{tabular}{ccc}
\hline Date & Slope area method & Flow model \\
\hline $11 / 7 / 1968$ & 52 & 45 \\
$27 / 9 / 1974$ & 25 & 27 \\
$30 / 5 / 1979$ & 58 & 54 \\
$12 / 7 / 1982$ & 78 & 77 \\
$29 / 6 / 1917$ & 178 & 180 \\
\hline
\end{tabular}


been in use for over 10 years. On 1 December 2005 it was able to predict the water level behind the flood detention dam upstream of Bruton to within $0.1 \mathrm{~m}$. This result is considered to be accurate enough to issue a flood warning with a lead time of about 2 hours if the predicted water level is expected to get within $0.2 \mathrm{~m}$ of the level at which flow down the spillway takes place.

\section{Calibration and Application to Ungauged Catchments}

There are many hydrological models which can be calibrated for one catchment. It is quite another to produce a method that can be applied when there is no riverflow data and even more demanding to provide a sensible flood warning. Hydrological reasoning suggested that the time to peak, Tp, not only depends on the rainfall intensity but also on the permeability of the soil. Thus the equation for the upper Brue was generalised:

$$
\mathrm{Tp}=\mathrm{c}\left(\mathrm{R}^{-0.17}\right) \mathrm{MSL} \text { catch/MSL Brue }
$$

MSL = mainstream channel length $(\mathrm{km})$ for the study catchment and Brue.

$$
c=7[\operatorname{INVLOG}(0.06633(50-\% \mathrm{R}))] / 1+\operatorname{INVLOG}(0.06633(50-\% \mathrm{R}))]
$$

where $\% \mathrm{R}=\%$ runoff at rainfall equal to $10 \mathrm{~mm} \cdot \mathrm{hr}^{-1}$, the $\% \mathrm{R}$ being based on the Ksat survey data for values $1 \%-50 \%$. For $\% \mathrm{R}>50 \%$ at rainfall $10 \mathrm{~mm} \cdot \mathrm{hr}^{-1}$, the equation for c becomes:

$$
c=3.5(0.98 \exp (\% \mathrm{R}-50))
$$

Adjustments for catchment slope and the mainstream catchment slope were also made. These changes were based on the Dudwell at Burwash, Ancholme at Toft Newton, and Brue at Bruton calibration catchments. The catchment and mainstream slope have correction factors. For catchment slope the correction factor $\left(\mathrm{S}_{\mathrm{cf}}\right)$ which best fit the data from 8 calibration catchments:

$$
\mathrm{Scf}=1.7[\operatorname{INVLOG}(0.35(\mathrm{~S}-3.30)) / 1+\operatorname{INVLOG}(0.35(\mathrm{~S}-3.30)]
$$

where $S$ = average catchment slope in degrees. This was assessed by counting the number of $10 \mathrm{~m}$ changes in elevation on 1:50000 OS maps in each grid square or part grid square over a distance of $1 \mathrm{~km}$. The results are summed and then applied:

$$
\operatorname{Tan}_{\text {slope }}=0.01[\mathrm{Sx} / \mathrm{A}]
$$

where $\mathrm{Sx}=$ sum of changes in land height, $\mathrm{A}=$ catchment area.

The lowest value of Scf is 0.292 as found for the Ancholme at Toft Newton. Its general form is that of a logistic in that there is a minimum and maximum value which is attained at an ever decreasing rate at both low and high slopes. The constant 3.30 is the average slope for both the Brue and Lud catchments. The constant 0.35 influences the rate at which the value of Scf changes with slope.

The correction for mainstream channel slope is based on the gradient of the last $10 \mathrm{~m}$ fall in the mainstream $(\mathrm{m} / \mathrm{km})$. Where the gradient is lower further upstream up to a point which includes $50 \%$ or more of total catchment area, this gradient should be used. Again, considerable experiment yielded the correction factor for mainstream slope $\left(\mathrm{MSS}_{\mathrm{cf}}\right)$ : 


$$
\mathrm{MSS}_{\mathrm{cf}}=(2 / \mathrm{L})^{\mathrm{F}}-\left(\mathrm{L}^{1.001}-\mathrm{L}\right)
$$

where $\mathrm{L}=$ distance between two $10 \mathrm{~m}$ contours on 1:50,000 OS maps, measured along the mainstream channel closest to the outlet.

$$
\text { F 0.7[(INVLOG }(\log 220-\log \mathrm{A}) / 1+\operatorname{INVLOG}(\log 220-\log \mathrm{A})
$$

with a minimum value of 0.3 . Where the point of interest is close enough to a confluence so that both tributaries are included in the $10 \mathrm{~m}$ height drop, the area weighted value of $\mathrm{L}$ is used. If $\mathrm{L}=$ or $<2.0 \mathrm{~km}$ then $\mathrm{MSScf}=1.0$.

Further adjustments for the lag time and time to peak of the delayed flow were made:

$$
\text { Lag/Tp = MSL catchment/MSL Brue }
$$

where MSL = mainstream channel length as shown on 1:50,000 OS maps. Delayed flow increases linearly upwards until it reaches the peak. Thereafter it decreases exponentially according to the decay constant k, (Equation (24)), which varies with catchment area $(\mathrm{A})$ via:

$$
\mathrm{k}=0.0247 \log \mathrm{A}+0.909
$$

This is applied to the delayed flow via:

$$
\text { Del } \mathrm{T}+1=\operatorname{Del} \mathrm{T} \exp \mathrm{k}
$$

The full description of how the model was calibrated for permeable catchments and the effects of urban areas and abstraction-mainly of importance for common events, is described in Clark [15].

For the estimation of SMD a weighing lysimeter is used in the upper Brue catchment. The design of this has already been described [4] and a comparison of the results with both MORECS [5] and MOSES [25] have been given. Big differences between the measured and calculated values makes its effect on provision of a flood warning considerable.

\section{Flood Warning for the Lynmouth Storm August 16 1952 Using the Flow Model}

This flood resulted from over 9 inches $(229 \mathrm{~mm})$ taking place in about 9 hours on a catchment which was already at field capacity. The effects of the resulting flood have been described by Delderfield [26], Prosser [27]. Figure 1 shows the daily rainfall which has recently been revised according to an analysis of the effect of elevation on rainfall depth during the storm.

There were no rainfall recorders in the local area but $22 \mathrm{~km}$ to the west at Chivenor and $15 \mathrm{~km}$ to the east at Wootton Courtenay the combined continuous records enabled an estimated rainfall profile to be constructed. Figure 2 shows the results.

The percentage runoff at different rainfall intensities was estimated by measuring the saturated hydraulic conductivity of the soils in the field using the core method [28] Arellano \& Clark, [29]. For each soil Association in the catchment at least 30 tests were made. The results were classified into $5 \mathrm{~mm}$ bands viz $0-5$, $5.1-10$ and so on as shown in Table 2. 


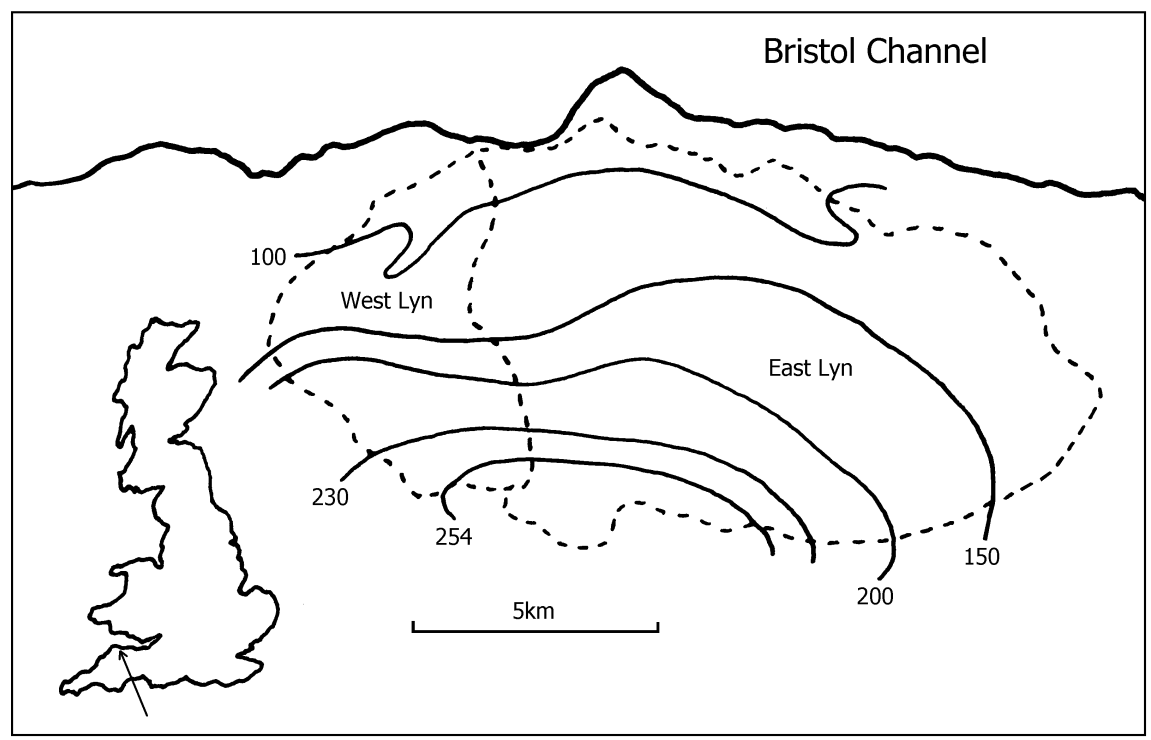

Figure 1. Daily rainfall for 16 August 1952.
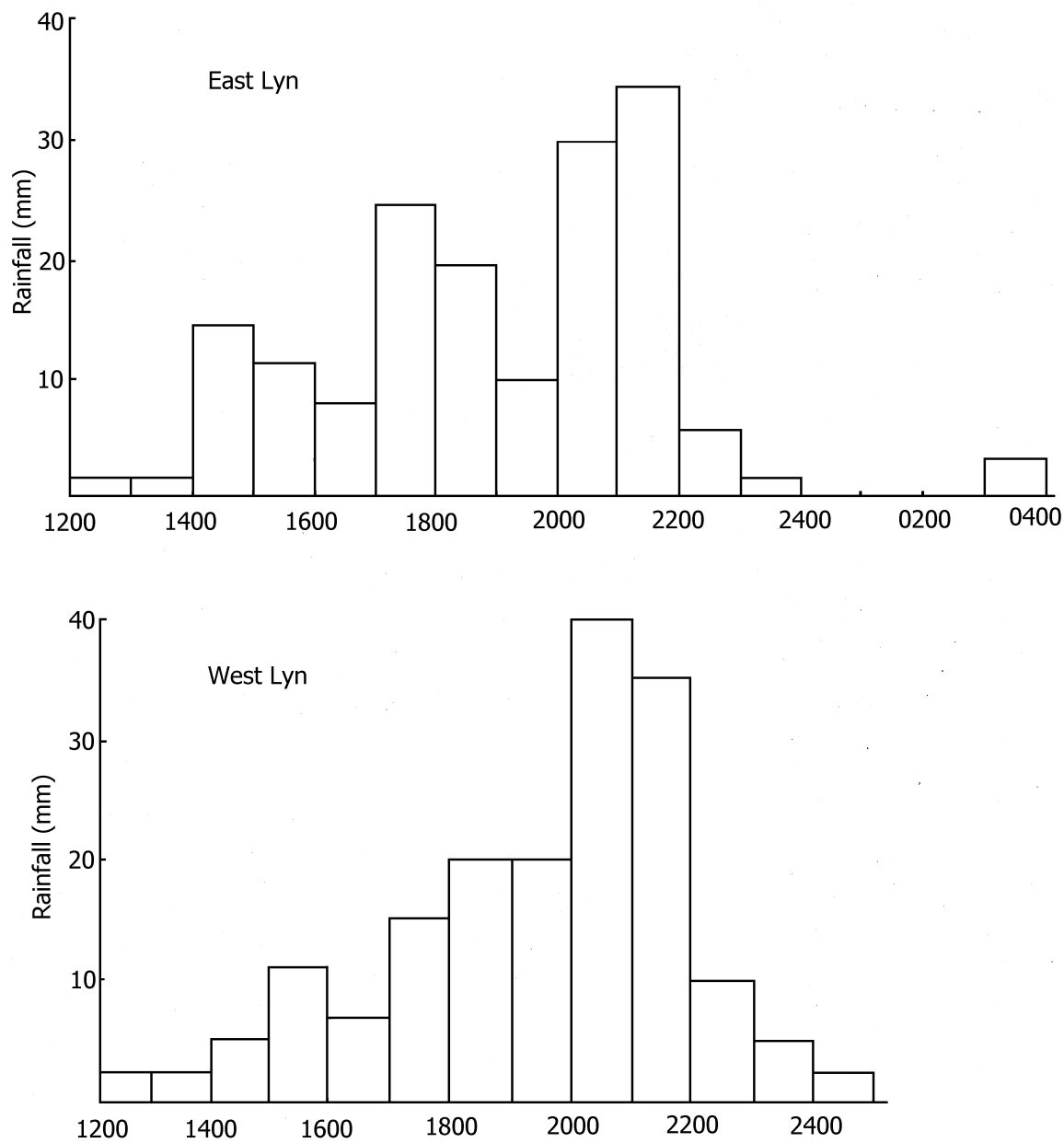

Figure 2. Estimated rainfall profiles for the East and West Lyn catchments.

Percentage runoff calculated from the midpoint in each class of conductivity: Eg. $20 \mathrm{~mm} \cdot \mathrm{hr}^{-1}$ percentage runoff $\left.=(20-2.5) \times 0.31\right) \times(20-7.5) \times 0.23+(20-$ 
$12.5) \times 0.20+(20-17.5) \times 0.11=50 \%$. The percentage cover of each Soil Association was then measured from the Reconnaissance Map [30], and the catchment average \% runoff calculated based on this and the conductivity values of each soil. Figure 3 shows the results.

The flow model is non-linear because of the response of soils to increasing rainfall intensity and the $\mathrm{UH}$ ordinates or rates of runoff per $\mathrm{mm}$ net rainfall being non linear with time.

Variables of the unit hydrograph method:

Time to peak (hours) $=$ c MSL catchment/ MSL Brue (9) $\left(\mathrm{R}^{-0.17}\right)$, where $\mathrm{R}=$ rainfall intensity $\mathrm{mm} \cdot \mathrm{hr}^{-1}$.

$\mathrm{MSL}=$ mainstream channel length (longest tributary) East Lyn $=17.27 \mathrm{~km}$.

$c=7[$ INVLOG $0.06633(50-\% R) / 1+\operatorname{INVLOG}(50-\% R)]$.

Table 2. Saturated hydraulic conductivity of the Lydcott Association (654b).

\begin{tabular}{cccc}
\hline Conductivity class $\mathrm{mm} \cdot \mathrm{hr}^{-1}$ & Number of tests & $\%$ & \% runoff \\
\hline $0-5$ & 11 & 31 & 29 \\
$5.1-10$ & 8 & 23 & 41 \\
$10.1-15$ & 7 & 20 & 50 \\
$15.1-20$ & 4 & 11 & 58 \\
$20.1-25$ & 3 & 9 & 64 \\
\hline
\end{tabular}

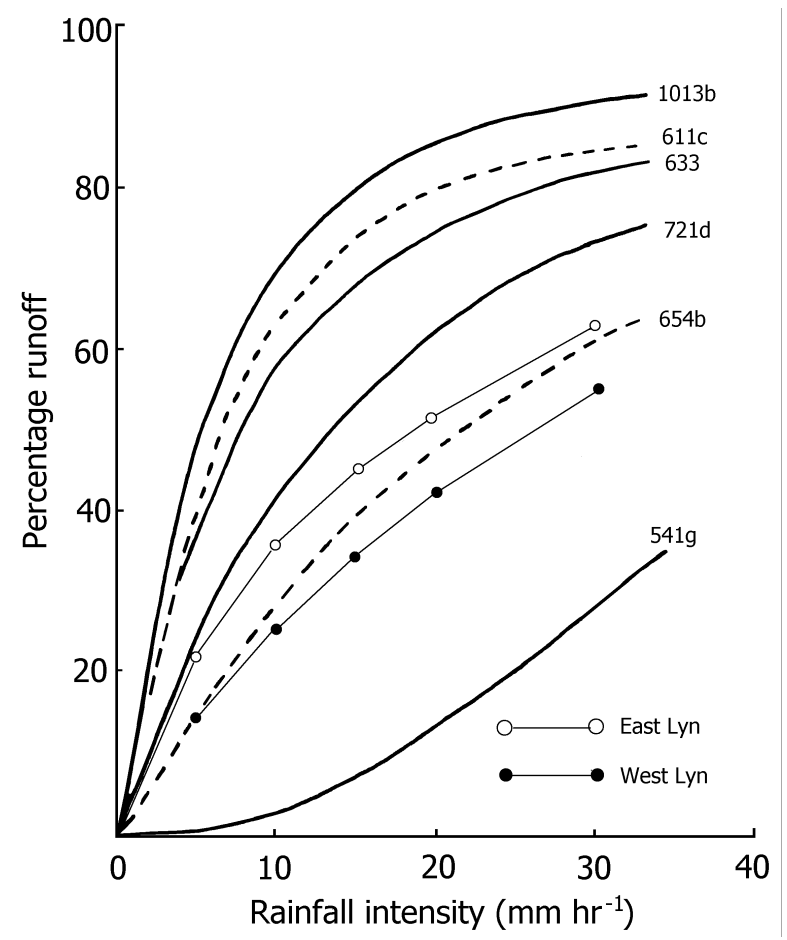

Figure 3. Saturated hydraulic conductivity of soils in the East and West Lyn. 
$\% \mathrm{R}=$ percentage runoff at $10 \mathrm{~mm} \cdot \mathrm{hr}^{-1}$ rainfall, based on soil hydraulic conductivity.

For the East Lyn $\% \mathrm{R}=36$. Thus $\mathrm{c}=6.2619$.

Time to peak $=12.015\left(\mathrm{R}^{-0.17}\right)$.

Time base $(\mathrm{TB})=2.52 \mathrm{Tp}$.

Peak quickflow ordinate $(\mathrm{Qp})=330 / \mathrm{Tp} \times$ catchment area/1000.

Ordinates $(\mathrm{Y})$ of the rising limb of the hydrograph:

$\mathrm{Y}=[\mathrm{INVLOG} 2(\mathrm{t}-0.7 \mathrm{Tp}] / 1+[\mathrm{INVLOG} 2(\mathrm{t}-0.7 \mathrm{Tp})] \mathrm{Qp}$.

For the falling limb: $\mathrm{Y}=\left[\mathrm{INVLOG}\left(\mathrm{t}_{1}-0.85(\mathrm{~TB}-\mathrm{Tp})\right) / 1+\operatorname{INVLOG}\left(\mathrm{t}_{1}-\right.\right.$ 0.85(TB $-\mathrm{Tp})$ )]Qp. Where $\mathrm{t}_{1}=\mathrm{TB}-\mathrm{T}$ where $\mathrm{T}=$ time since start of storm.

The model is unique in that $\mathrm{Tp}, \mathrm{TB}$, and Qp will change at each stage of the storm according to the rainfall intensity. Slope runoff $=\mathrm{R}$ [sine average catchment slope (degrees)] = R [0.01 (N/A)] where $\mathrm{N}=$ sum of contour crossings in each grid square or part thereof on a 1:50,000 OS map over a straight or curved distance of $1 \mathrm{~km}$. A = catchment area. For East Lyn sine slope $=0.142$.

Slope correction factor

$(\mathrm{Scf})=1.7[\operatorname{INVLOG}(0.35(\mathrm{~S}-3.30)) / 1+\operatorname{INVLOG}(0.35(\mathrm{~S}-3.30))]$ where $\mathrm{S}=$ average catchment slope (degrees). For the East Lyn Scf $=1.667$

Mainstream channel slope correction factor $=1.0$ since distance between river channel contours $<2.0 \mathrm{~km}$.

Hourly storm intensity, East Lyn: 2, 2, 15, 12, 8, 25, 20, 10, 30, 35, 6, 2

Extract of results:

\begin{tabular}{|c|c|c|c|c|c|c|c|c|c|}
\hline \multicolumn{3}{|c|}{ Rainfall intensity $\left(\mathrm{mm} \cdot \mathrm{hr}^{-1}\right)$} & \multicolumn{2}{|c|}{$\mathrm{Tp}$} & $\mathrm{TB}$ & \multicolumn{3}{|c|}{$0.85(\mathrm{~TB}-\mathrm{Tp})$} & Qp \\
\hline \multicolumn{3}{|c|}{2} & \multicolumn{2}{|c|}{10.679} & 26.912 & \multicolumn{3}{|c|}{13.798} & 2.384 \\
\hline & 8 & & \multicolumn{2}{|c|}{8.437} & 21.261 & \multicolumn{3}{|c|}{10.901} & 3.017 \\
\hline & 10 & & \multicolumn{2}{|c|}{8.123} & 20.470 & \multicolumn{3}{|c|}{10.495} & 3.133 \\
\hline & 15 & & \multicolumn{2}{|c|}{7.582} & 19.106 & \multicolumn{3}{|c|}{9.796} & 3.357 \\
\hline & 12 & & \multicolumn{2}{|c|}{7.875} & 19.485 & \multicolumn{3}{|c|}{10.174} & 3.232 \\
\hline & 20 & & \multicolumn{2}{|c|}{7.220} & 18.194 & \multicolumn{3}{|c|}{9.328} & 3.526 \\
\hline Runoff: & \multicolumn{9}{|c|}{ Hourly rainfall intensity $(\mathrm{mm})$} \\
\hline SR & 2 & 2 & 15 & 12 & 8 & 25 & 20 & 10 & 30 \\
\hline K & 0.28 & 0.28 & 2.13 & 1.79 & 1.70 & 3.55 & 2.84 & 1.42 & 4.26 \\
\hline $\mathrm{T}$ & 0.13 & 0.13 & 5.29 & 3.81 & 1.87 & 11.30 & 8.16 & 2.74 & 14.90 \\
\hline SR & 0.41 & 0.41 & 7.42 & 5.51 & 3.00 & 14.85 & 11.00 & 4.16 & 19.16 \\
\hline Del & 1.59 & 1.59 & 7.58 & 6.49 & 4.00 & 10.15 & 9.00 & 5.84 & 10.84 \\
\hline
\end{tabular}

where SR = slope runoff; $K=$ runoff from the soil (hydraulic conductivity) $\mathrm{T}=$ $\mathrm{SR}+\mathrm{K}$. Del $=$ Rainfall $-\mathrm{T}$. 


\begin{tabular}{ccccccccccc}
\hline \multicolumn{10}{c}{ Clock Hour } \\
\hline $\mathrm{T}$ & 1800 & 1900 & 2000 & 2100 & 2200 & 2300 & 2400 & 0100 & 0200 & 0300 \\
0.41 & 0.002 & 0.240 & 2.188 & 2.383 & 2.379 & 2.365 & 2.214 & 1.347 & 0.274 & 0.030 \\
0.41 & - & 0.002 & 0.240 & 2.188 & 2.383 & 2.379 & 2.365 & 2.214 & 1.347 & 0.274 \\
7.42 & 0.008 & 0.655 & 3.224 & 3.356 & 3.200 & 2.253 & 0.567 & 0.067 & 0.006 & - \\
5.51 & - & 0.003 & 0.278 & 2.922 & 3.228 & 3.081 & 2.171 & 0.549 & 0.064 & 0.006 \\
4.00 & - & - & - & 0.043 & 1.829 & 2.997 & 3.016 & 2.890 & 2.100 & 0.562 \\
14.85 & - & - & - & 0.133 & 2.969 & 3.589 & 3.586 & 2.467 & 0.598 & 0.069 \\
11.00 & - & - & - & - & 0.027 & 1.544 & 3.481 & 3.526 & 3.003 & 1.493 \\
4.16 & - & - & - & - & - & 0.001 & 0.127 & 2.555 & 3.125 & 3.132 \\
19.16 & - & - & - & - & - & - & 0.133 & 2.969 & 3.589 & 3.596 \\
23.90 & - & - & - & - & - & - & 0.004 & 0.335 & 3.358 & 3.872 \\
2.00 & - & - & - & - & - & - & - & - & - & 0.011 \\
0.41 & - & - & - & - & - & - & - & - & - & - \\
& 0.06 & 4.97 & 26.4 & 45 & 95 & 118 & 125 & 165 & 214 & 198 \\
\hline
\end{tabular}

Extract from the unit hydrograph calculations is shown below. Body of the Table are ordinates $\left(\mathrm{m}^{3} \cdot \mathrm{s}^{-1} \cdot \mathrm{mm}^{-1}\right.$ runoff. $\mathrm{T}=$ total runoff for each rainfall intensity. Total discharge is sum of the products at each time: eg. at $7 \mathrm{pm}=0.41 \times$ $0.240+0.41 \times 0.002+7.42 \times 0.655+5.51 \times 0.003=4.97$. The discharges are cumecs $\left(\mathrm{m}^{3} \cdot \mathrm{s}^{-1}\right)$. The ordinates for delayed flow are $0.15 \mathrm{~m}^{3} \cdot \mathrm{s}^{-1} 31 \mathrm{~km}{ }^{-2}$ which is for rock Group D2 and D1 [14]. The time to peak and lag time of delayed flow = MSL catch/MSL Brue. Linear increase in the ordinates up to peak and exponential decay rate thereafter viz: decay constant $=0.0247 \log A+0.909$.

Total discharge $=$ Scf $\times$ quickflow + delayed flow: $(1.667 \times 214)+23.5=380$ $\mathrm{m}^{3} \cdot \mathrm{s}^{-1}$. Baseflow is added via $\mathrm{Q}=\mathrm{CA}(\mathrm{INVLOG}[0.0005372 \mathrm{SAAR}-2.3114])=3$ cumecs therefore $\mathrm{Q}=383 \mathrm{~m}^{3} \cdot \mathrm{s}^{-1}$.

Figure 4 shows the complete hydrographs for the East and West Lyn. The main events of the flood have been simulated. This gives a measure of the robustness of the method in view of the extreme nature of the storm with more than one rainfall peak. The falling limb should have been about 30 minutes earlier. This would have allowed PC Derek Harper to get across the parapet of Countisbury Bridge by $0400 \mathrm{~h}$ [27]. The peak discharges of 384 and 162 cumecs for the East and West Lyn respectively are 8\% and 36\% lower than the results of Dobbie and Wolf [31].

Taking the West Lyn first the heavy rainfall up to $1800 \mathrm{hrs}$ gives no cause for concern. By 1900 hrs considerable overflow in Lynmouth is predicted since the discharge has become about double the channel capacity. People warned might simply move upstairs perhaps taking special belongings. By $2000 \mathrm{~h}$ the situation would look not much worse but by $2030 \mathrm{~h}$ there was a clear sign that people should evacuate at once. Recall now the events $2 \mathrm{~km}$ upstream at Barbrook [26]. At some time after $2130 \mathrm{~h}$ Tom Floyd looked out to see the raging river, but by then it was too late. Fortunately Tom, his daughter, and dog Tim survived, but 


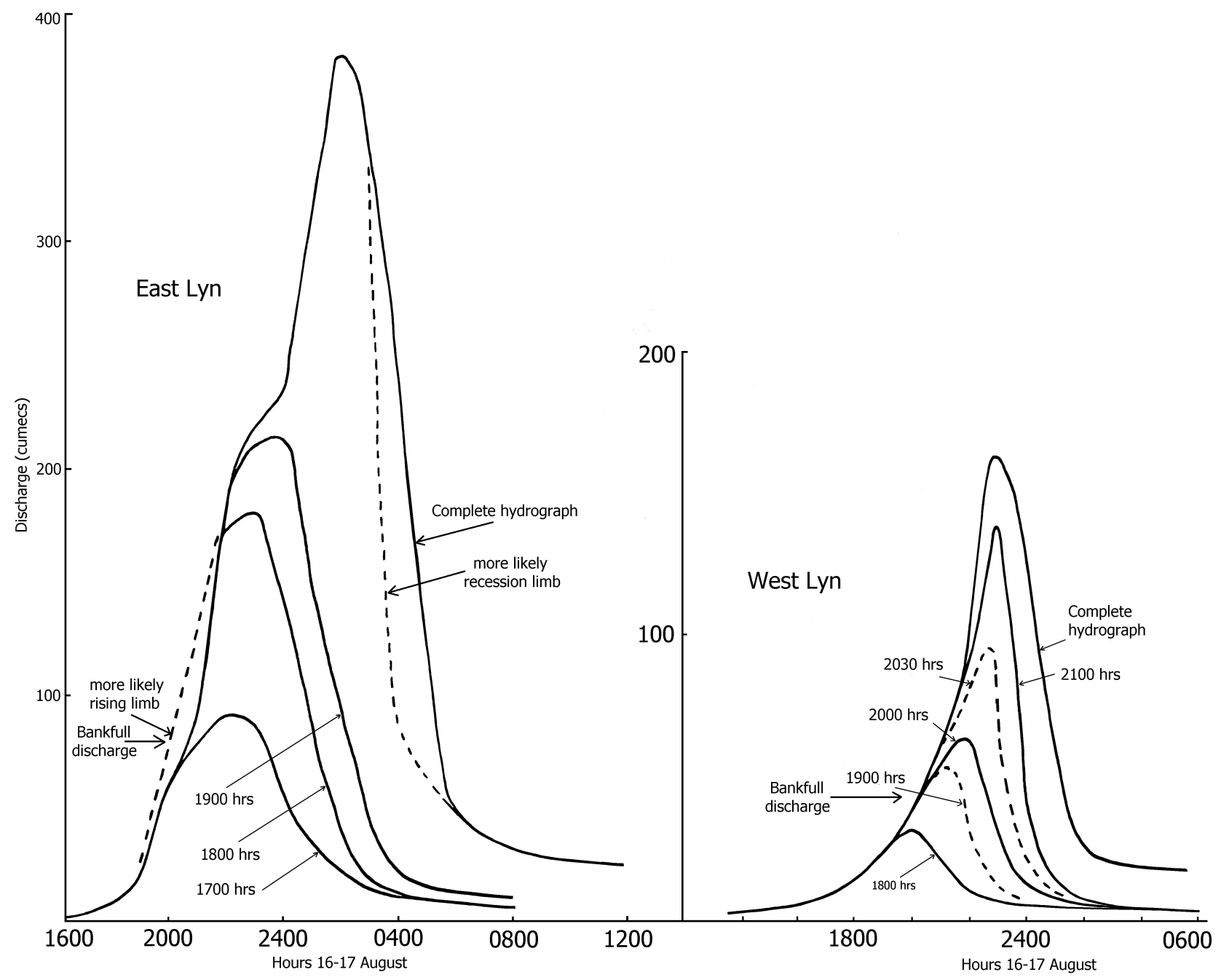

Figure 4. Predicted hydrographs for the East and West Lyn. The time of each forecast is shown.

the rest of his family were drowned [27]. We can now say that at least 1 hour's warning could have been given to the people at Barbrook, where four of the cottages were destroyed. On the East Lyn the longer travel distance gave more time to evacuate since by $1800 \mathrm{~h}$ the prediction of a life threatening flood is clear (Figure 4). Comparing the timing of this knowledge with events on the ground gives us hope for the future provision of flood warnings in the UK. At Bevan's Cottages on the East Lyn the doors burst open at about $2150 \mathrm{~h}$. Thus over three hours warning could have been given. Such is the sad loss of life for want of a timely flood warning!

\section{Flood Warning for Boscastle}

This event is included in this paper because the flow model was able to predict the flood with just over one hour warning. What has been described as the miracle of Boscastle is the fact that no one was drowned. However, several people, including visitors in the Wellington Hotel, had an escaped with a matter of a few minutes to spare, while a child sat on the bonnet of a car was grabbed seconds 
before the car was swept away. That the event happened in the day may have meant fewer people were present as visitors but the situation could have been a lot worse like at Lynmouth where people were tending to have a quiet evening indoors.

The storm was caused by a complex area of low pressure to the west with unstable air developing during the morning [32]. During a four hour period over $180 \mathrm{~mm}$ were recorded at Lesnewth which is close to the centre of the Valency catchment which discharges into the Atlantic Ocean at Boscastle. Figure 5 shows the storm rainfall at a resolution of $0.25 \mathrm{hr}$.

The flow model used locally gathered soil hydraulic conductivity data. Full details of the application are given in Clark [14]. The river Valency started to overflow by $1515 \mathrm{hr}$. Three simulations were made and that for $1415 \mathrm{hr}$ showed that a substantial flood was about to begin: a serious flood warning would then have been issued. Figure 6 shows the results.

The success of the model in giving a realistic estimate of the complete flood is shown in Figure 7. Calculations of the likely SMD showed that it was about 12 $\mathrm{mm}$ [33]. In contrast to this the MOSES PDM [34] suggested a value in excess of $100 \mathrm{~mm}$ which was far too high based on the rainfall regime earlier in the year and that at CHRS the weighing lysimeter on the same day was about $30 \mathrm{~mm}$

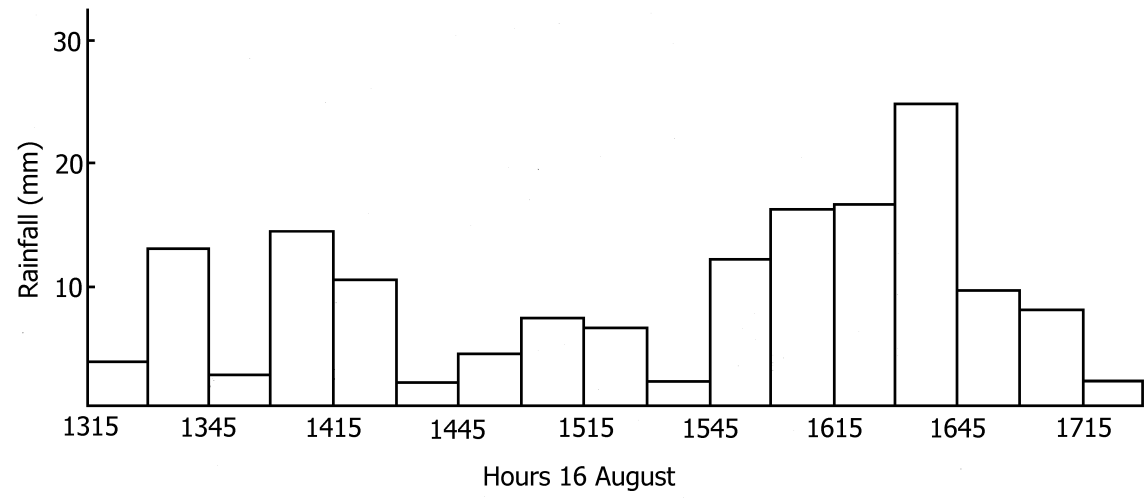

Figure 5. Storm rainfall at Lesnewth 16 August 2004.

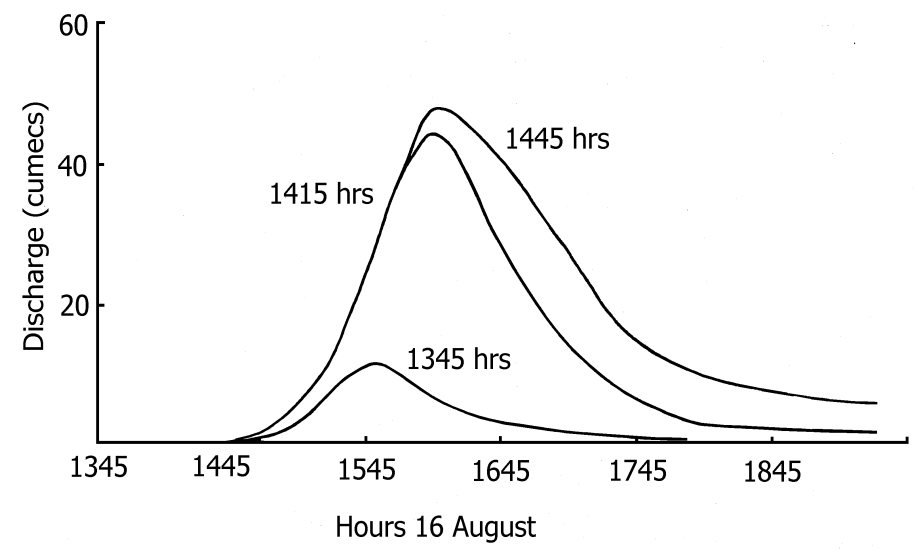

Figure 6. Estimated hydrographs for 16 August. The time of each forecast is shown. 


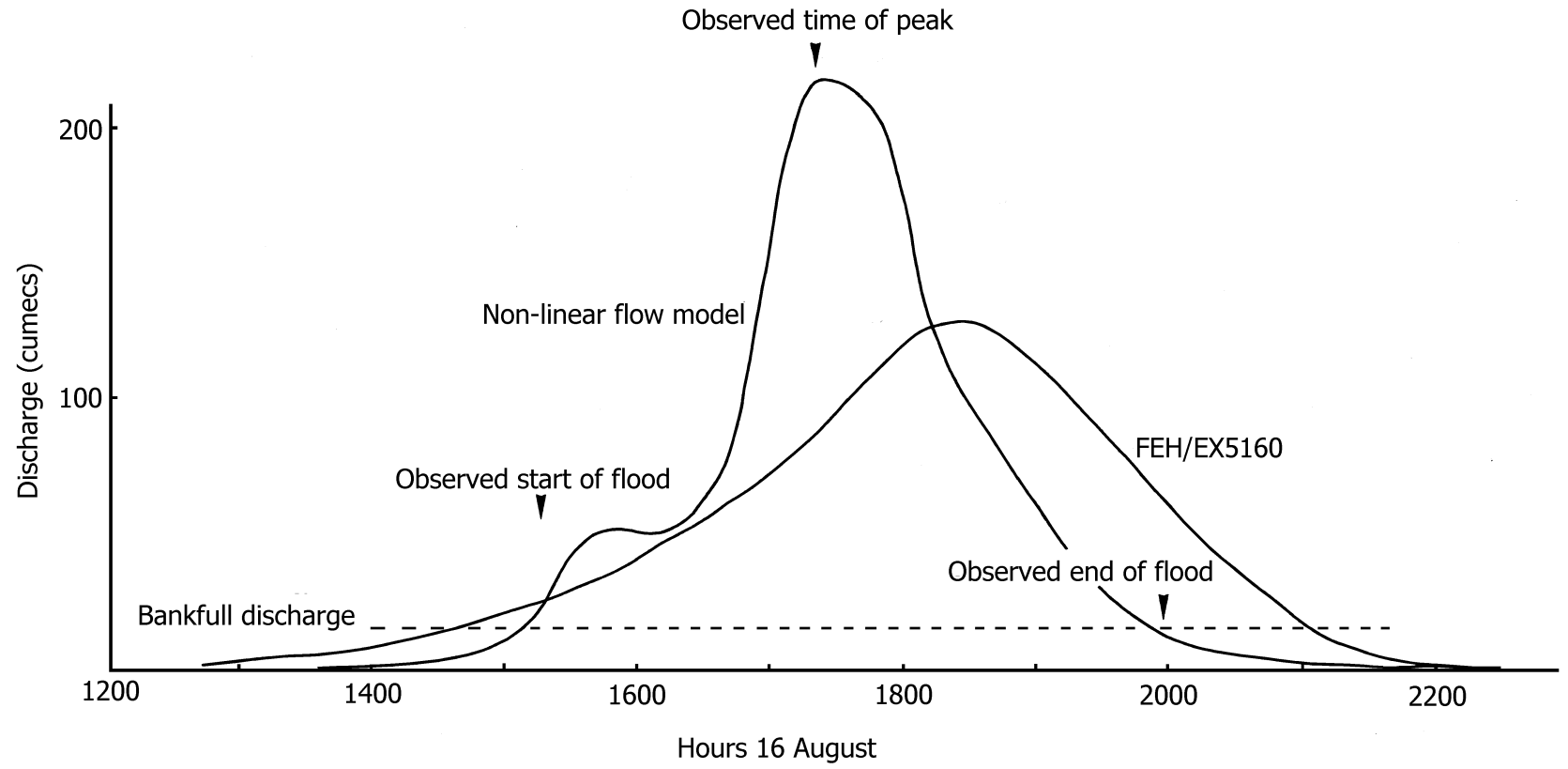

Figure 7. Estimates of the discharge for 16 August 2004 at Boscastle [35].

SMD but with a lower rainfall in the previous three months. The lysimeter is 235 mm diameter and the soil about $330 \mathrm{~mm}$ deep, and costs about $£ 25$ to construct.

\section{Discussion}

Timely flood warnings are essential during a serious flash flood if lives are to be saved. The method described here uses local data for rainfall and soil hydraulic conductivity. The use of a low cost lysimeter in order to get realistic estimates of SMD has been briefly mentioned. This approach is much more realistic than other methods which fail to produce timely warnings. In a country which already has some places protected up to about the 1 in 100 year design standard the need for flood warning is even more important in the event of the scheme being overwhelmed by a very rare flood. There are also other places without any protection or even a flood warning scheme. For catchments below about $15 \mathrm{~km}^{2}$ the lead time for a warning becomes less than 1 hour. Giving a false warning will undermine the confidence of future warnings so it is essential that accurate rainfall and catchment data are used. It is very much hoped that the techniques described here can be adopted in other countries.

\section{References}

[1] Penning-Rowsell, E., Tapsell, S. and Wilson, T. (2005) Key Policy Implications of the Health Effects of Floods. Extreme Weather Events and Public Health Responses, WHO, Springer, 207-223.

[2] Sene, K. (2012) Flash Floods: Forecasting and Warning. Springer, 385 p.

[3] Collier, C.G. (2007) Flash Flood Forecasting: What Are the Limits to Predictability? Q.J.R. Meteorol. Soc., 133, 3-23. https://doi.org/10.1002/qj.29

[4] Clark, C. (2013) Measurements of Actual and Pan Evaporation in the Upper Brue 
Catchment UK: The First 25 Years. Weather, 68, 200-208.

https://doi.org/10.1002/wea.2090

[5] Clark, C. (2002) Measured and Estimated Evaporation and Soil Moisture Deficit for Growers and the Water Industry. Meteorl. Appl., 9, 85-93. https://doi.org/10.1017/S1350482702001093

[6] Smith, P. and Bevan, K. (2014) When to Issue a Flood Warning: Towards a RiskBased Approach Based on Real Time Probabilistic Forecasts. Proc. $2^{\text {nd }}$ International Conference and Analysis and Risk Management. ASCE Conference, 1395-1404. https://doi.org/10.1061/9780784413609.140

[7] Kimura, N., Hsu, M.-H., Tsai, M.-Y., Tsao, M.-C., Lu, S.-L. and Tai, A. (2016) A River Flash Flood Forecasting Model Coupled with Ensemble Kalman Filter. J. Flood Risk Mangt, 9, 178-192. https://doi.org/10.1111/jfr3.12128

[8] Parker, D.J. (2007) Advances and Challenges in Flash Flood Warnings. Env. Hazards. , 7, 173-178.

[9] HMG (2016) National Flood Resilience Review. 141 p.

[10] DEFRA (2016) Future Flood Prevention. Environment Food and Rural Affairs. 53 p. House of Commons.

[11] Land Drainage Act (1976) HMSO. London.

[12] Environment Agency (2005) The Floods in Boscastle and North Cornwall 16 August 2004. $29 \mathrm{p}$.

[13] Clark, C. (2004) A Nonlinear Unit Hydrograph Model for Real Time Flood Forecasting below a Dam. Internat. Water Power \& Dam Constr, 56, 20-26.

[14] Clark, C. (2006) A Real Time Flood Warning System for Boscastle, North Cornwall. Report to Environment Agency, Exeter, 18 p.

[15] Clark, C. (2012) Spillway Design Flood and Flood Volume Estimated Using the New Guide to Flood Estimation. In: Wong, T.S.W. Ed., Flood Risk and Flood Management, Nova Science, New York, 219-255.

[16] Ciervo, F., Papa, M.N., Medina, V. and Bateman, A. (2015) Simulation of Flash Floods in Ungauged Basins Using Post Event Surveys and Numerical Modelling. J. Flood Risk. Mangt, 8, 343-355.

[17] WMO (2011) Manual on Flood Forecasting and Warning. WMO No. 1072.

[18] Sherman, L.K. (1932) Streamflow from Rainfall by Unit-Graph Method. Eng. News Record, 108, 501-505.

[19] Young, P.C. and Bevan, K.J. (1994) Data Based Mechanistic Modelling and the Rainfall-Flow Nonlinearity. Environometrics, 5, 335-363. https://doi.org/10.1002/env.3170050311

[20] Sivakumar, B. (2008) The More Things Change, the More They Stay the Same: The State of Hydrologic Modelling. Hydrol. Process, 22, 4333-4337. https://doi.org/10.1002/hyp.7140

[21] Street, H.E. and Opik, H. (1970) The Physiology of Flowering Plants. Edward Arnold, London, $263 \mathrm{p}$.

[22] Ashfaq, A. and Webster, P. (2000) The Timing of Runoff Response in Design Flood Analysis. Hydrol. Process, 14, 1217-1233. https://doi.org/10.1002/(SICI)1099-1085(200005)14:7<1217::AID-HYP36>3.0.CO;2-5

[23] Clark, C. and Pike, W.S. (2007) The Bruton Storm and Flood after 90 Years. Weather, 62, 300-305. https://doi.org/10.1002/wea.142

[24] Clark, C. (1996) Floods at Bruton past Present and Future. $2^{\text {nd }}$ Ed. Charldon Publications, Bruton, $86 \mathrm{p}$. 
[25] Clark, C. (2009) The Use of Local Data in Predicting and Estimating Extreme Floods. 635-646 in Water, Environment, Energy, and Society. (WEES 2009). Vol II Statistical and Systems Analysis Techniques. New Delhi 12-16 January 2009. Allied Publishers, Mumbai.

[26] Delderfield, E. (1981) The Lynmouth Flood Disaster. E.R.D. Publications Ltd. Exmouth. $10^{\text {th }} \mathrm{Ed}$.

[27] Prosser, T. (2001) The Lynmouth Flood Disaster. Lyndale Photographic Pub. 99 p. Lynmouth.

[28] Hollis, J.M. and Woods, S.M. (1989) The Measurement and Estimation of Saturated Soil Hydraulic Conductivity. Soil Survey \& land res. Centre, Silsoe, 19 p.

[29] Arellano, A.L. and Clark, C. (2004) The Louth Storm and Flood after 80 Years. Weather, 59, 71-76. https://doi.org/10.1256/wea.25.03

[30] Soil Survey England and Wales (1984) Legend for the 1:250,000 soil map of England and Wales. 21 p.

[31] Dobbie, C.H. and Wolf, P.O. (1953) The Lynmouth Flood of August 1952. Pro. Inst. Civ. Engrs., 2, 522-588. https://doi.org/10.1680/ipeds.1953.12369

[32] Golding, B., Clark, P. and May, B. (2005) The Boscastle Flood: Meteorological Analysis of the Conditions Leading to Flooding on 16 August 2004. Weather, 60, 230-235. https://doi.org/10.1256/wea.71.05

[33] Clark, C. (2005) Catastrophic Floods: Magnitude and Frequency Investigations. Internat. Water Power \& Dam Constr., 57, 14-21.

[34] HR Wallingford (2005) Flooding in Boscastle and North Cornwall, August 2004. EX5160. 169 p.

[35] Clark, C. (2006) Planning for Floods: Will We Ever Learn? Internat. Water Power \& Dam Constr, 58, 20-27.

\section{Submit or recommend next manuscript to SCIRP and we will provide best} service for you:

Accepting pre-submission inquiries through Email, Facebook, LinkedIn, Twitter, etc. A wide selection of journals (inclusive of 9 subjects, more than 200 journals)

Providing 24-hour high-quality service

User-friendly online submission system

Fair and swift peer-review system

Efficient typesetting and proofreading procedure

Display of the result of downloads and visits, as well as the number of cited articles

Maximum dissemination of your research work

Submit your manuscript at: http://papersubmission.scirp.org/

Or contact gep@scirp.org 